\title{
Building Common Knowledge: negotiating new pedagogies in Higher Education in South Africa ${ }^{1}$ DRAFT
}

\author{
Shirley Walters, Freda Daniels, Vernon Weitz
}

\begin{abstract}
Discussions in this chapter are located within an action research-based study which aims at supporting the integration of enhanced pedagogies in one university in South Africa. The study recognises that even full-time funded students in Higher Education face economic pressures which mean that student employment alongside full-time study is approaching the norm. It also recognises that this situation has implications for the pedagogies that are used by university departments, whether students are preparing directly for the professions or undertaking more open-ended courses. In this chapter we focus on how one university initiative to create more responsive pedagogies has been negotiated into the practices of three departments in one university with a strong history of engaging first generation university students who are poor.

In particular, we draw on the idea of common knowledge to explain how new understandings of pedagogy are negotiated into the practices by the core team and are then deployed institutionally. We identify and discuss the political nature of organisational innovation and the building of common knowledge, through discussing an illustrative 'moment' from the research project and the participatory research approach that we adopt. The chapter brings together analytic resources of cultural-historical theory, a participatory research approach and, in particular, ideas of relational expertise, common knowledge and relational agency.
\end{abstract}

\section{SETTING THE SCENE}

Presently, public Higher Education Institutions in South Africa are under pressure to increase their intake of young students which can mean that working people or 'non-traditional students' (adults) are finding their options for lifelong learning being limited, including their ability to gain access through recognition of prior learning (RPL). At a time when public policy commitment is to open and widen access to workers and adult learners, the 'doors of learning' paradoxically are closing (RSA 2013; Buchler et al 2007). This chapter describes institutional research within one historically black university in South Africa, which was at the forefront of the anti-apartheid struggle, and has a 50 year tradition of providing access to working class and first generation students. We sketch contradictory contextual conditions, changing priorities, and institutional contestations, which are impacting opportunities for poor and working students profoundly. We describe the situation which has led to an action research project on 'flexible learning and teaching provision' directed primarily for working people. It describes the overall approach to the action research, including the identification of key conceptual tools of 'common knowledge' and 'relational expertise'.

\footnotetext{
${ }^{1}$ We wish to acknowledge that the action research that forms the basis of this chapter has been done in partnership with the South African Qualifications Authority (SAQA). The ideas expressed, however, are the authors alone.
} 
The research is concerned to assist the university realise a philosophy and approach to lifelong learning under new and changing conditions. While the research focuses on the inter-relationships between the students, their working lives and the university - the primary question is 'how can the university respond meaningfully to the real circumstances of students to enhance prospects for their professional development?' In addressing that question the study is also concerned with the process of influencing organisational change through the research. In brief, the study sets out to explore, using an action research orientation, how the university can develop more appropriate pedagogical approaches to help working students to succeed. This aim entails understanding the working lives of students, engaging their workplaces, and influencing the teaching, learning and administrative environment of the university.

Located within more extensive analyses of the national and global contexts (Walters 2012; Barnett 2014), the key contradiction, to which the research responds, is that access is being limited, through the closure of after-hours or evening classes, at a time and in a place where access for working and first generation students is a core part of the university's historic mission. The issue is politically charged and carries with it certain moral obligations relating to social justice for the black majority who have been severely disadvantaged through the history of colonialism and Apartheid. The university, like many others, finds itself in the cross winds of global capitalism where corporatisation of universities is a widespread phenomenon. As Burawoy (2011: 27) states, 'These pressures come in two forms - commodification and regulation'. These include international ranking systems; the invasion of market logic in every dimension of the institution; research measurement systems which reduce research to publications in refereed journals, and so on. An added dimension, coming from the Apartheid past, is that in South Africa, the historically black university (HBU) finds itself in fierce competition with the more advantaged historically white universities (HWU).

As illustrative of the political struggle for the 'heart and soul' of the university, within the geopolitical global and national contexts, is a very public spat which reached the press, between the Chair of UWC Council, who was also president of the Convocation, and the Executive Management (Cape Argus 6, 9 and 13 June 2014). Part-time studies is implicated as referenced by the journalist (Cape Argus, June 8, 2014) when he says,

".....over the years nearly 50000 black and working class students, who would in all probability, otherwise not have had access to higher education, were able to pursue their studies part-time under the umbrella of UWC's lifelong learning programme. Historically, very many of these law students upgraded their qualifications while at the same time earning a living.......but in 2011, a decision was taken by the university's law faculty.....to shut down its part-time teaching programme....."

A week later (Cape Argus June 13, 2014 p21), a prominently positioned article by university senior management, entitled, "The doors of part-time learning still open at UWC", appeared. The authors located the problem as, "Demand for after-hours classes has dropped over the years, while student numbers in full-time study increased rapidly; though without a concomitant increase in the staffing budget." This argument highlights a central conundrum around prioritisation and allocation of scarce resources and, because the university leaders point to the action research projects, which are the focus of this chapter as "pilot sites for the exploration of modes of mixed or flexible delivery, which 
may be extended to other qualifications if they prove successful", the study provides an opportunity to examine the contradictions that comprise the conundrum.

In brief, 'part-time studies' seems to have become a proxy for the deeper political contestation around the priorities and future direction of the university. As a consequence, the action research initiatives have been buffeted by the political and pedagogical winds relating to the university's broader mission. The core research team, in its primary role of oversight of the action research and monitoring of its success, have been conscious of the project's political character. Indeed they have engaged in it precisely because of their political concern for equity and redress for black adults who have been denied opportunities through past and present colonialist, Apartheid and neo-liberal policies and practices.

\section{BACKGROUND, PURPOSE AND APPROACH OF THE STUDY}

In early 2010 a UWC Senate document (DLL 2010) proposed an action research project in flexible provision. It described some fundamental shifts taking place in the institution in response to a range of different pressures. It was, for example, becoming clear that due to resource pressures, including increased numbers of young students, and issues relating to the under-preparedness of students from school, it was no longer possible to envisage parallel delivery systems - one 'full time' and the other 'part time' in day time and after-hours slots. It was also widely recognized that UWC students, both under-graduate and post-graduate, were financially constrained, which meant they sought employment even while studying full time. This recognition was also reflected in increasing patterns of 'stop out' that have been raised in other surveys (Breier et al., 2008). Institutional research (DLL 2010) had already raised serious questions about the ambiguity in the distinction between 'part time' and 'full time' students, finding that sizable numbers of 'full time students' studied in the evening and vice versa; this ambiguity placed a question mark over the usefulness of these student descriptors. In particular, students entering through Recognition of Prior Learning (RPL) were frequently in employment and not able to attend classes during the day, a matter of some relevance to UWC, which had positioned itself nationally as a leader in promoting alternative access. The university was also, in line with global trends, increasing its E-learning capacities exponentially amongst staff and students; and facilities like the main library were remaining open for longer hours.

With these, and other, contextual conditions in mind, the proposal for an action research-based project was adopted in order to help shift the institution to embrace 'flexible learning and teaching provision 'through the adoption of pilot action research sites. Three pilot sites i.e. Departments of Library and Information Science, Political Studies and School of Public Health, were agreed. The key research question for the action research pilots was: what conditions need to change in order to give working people access to achieve success through higher education? The action research in each site was coordinated by a small research team in the cross-faculty, boundary-spanning (Akkerman and Bakker, 2011) Division for Lifelong Learning (DLL).

The research team was, from the start, very aware of the university-wide implications and was in agreement with Green et al (2013:26) who state that, because higher education is a complex system consisting of "four inter-dependent sub-systems" - teacher, learner, delivery and administrative subsystems - innovative approaches to learning and teaching would require profound shifts in the way that the entire university views, engages with and develops knowledge. This ambitious undertaking 
would require organisational change strategies which Johnston (1997) describes as both top down and bottom up.

In line with this understanding, the research project obtained endorsements through a range of committees including Senate. As researchers, we worked within a set of understandings which included the need for: strong support from the leadership of the institution so that the project could be seen as a strategic priority; resource incentives to encourage involvement in innovative teaching in the pilot sites; development of principles and processes for involvement which ensured a sense of fairness and equity; use of leading innovators, as far as possible, from other departments to support or work with colleagues; development of project teams for each pilot site which related back to the overall coordinating research team; development of a communications strategy to back up and support the pilot sites so that they did not remain isolated pockets of innovation but had the possibilities to influence others; communication of 'leading practices' on campus and elsewhere that already existed, to illustrate potential; speed to move quickly while the need for change was obvious and people were willing to innovate; development of a community of scholarship which excited colleagues intellectually and which could lead not only to 'flexible teaching and learning provision' but also to publishable research results.

However, while it has been important to keep these criteria in mind, in reality, not all of them could be met. In particular, the university was financially constrained and unable to contribute additional finances to the research. This lack of university investment signalled the paradox which was indicated at the start of the chapter and which was reflected in a series of contradictions as the pilots proceeded. Despite the lack of university financial support, the initiative went ahead with external funding from the South African Qualifications Authority (SAQA) for a three year partnership. However, no university investment has meant that the pilots have been positioned as additional work demanding a high degree of commitment from hard-pressed faculty-based colleagues.

We recognised that for institutional change to have a chance, the research needed to be collaborative and 'owned' as widely as possible. Organising structures were set up linking the pilot sites, to the research team, to a reference group which was a sub-committee of the Senate Teaching and Learning Committee (STLC) and to annual review and strategic planning meetings - all meeting regularly, ensuring close connections and collaborative relationships amongst the research team at the DLL who were expert in innovative pedagogies and the action researchers in departments, whose expertise lay particularly in their specialist knowledge. The project can also lay claim to substantial bureaucratic by-in as evidenced in the substantial meeting and reporting documentation presented to and discussed in committee and strategic planning meetings. However, given the institutional political environment, competing views on the significance of the project have been apparent. These conflicts were of course expected, given the contradictions we have already alluded to. As Castells explains:

...societies are not communities, sharing values and interests. They are contradictory social structures enacted in conflicts and negotiations among diverse and often opposing social actors. Conflicts never end: they simply pause through temporary agreements and unstable contracts that are transformed into institutions of domination by those social actors who achieve an advantageous position in the power struggle, albeit at the cost of allowing some 
degree of institutional representation for the plurality of interests and values that remain subordinated. So, the institutions of the state and, beyond the state, the institutions, organizations, and discourses that frame and regulate social life are never the expressions of 'society'.... They are crystallized power relationships; that is the 'generalized means' that enable actors to exercise power over other social actors in order to have the power to accomplish their goals. (Castells, 2009, p. 14)

If we accept the view that power struggles are inevitable, then we cannot assume that the debates and discussions within university are politically neutral. This understanding in turn places more pressure on the politics of the ideas of 'common knowledge' and 'relational expertise', to which we will return later.

Finally, in setting the scene, it is important to emphasise that funding to support the research was accessed through a partnership with the SAQA, which is a statutory body with oversight for the National Qualifications Framework (NQF). SAQA's mandate includes facilitating access to, and mobility and progression within education, training and career paths in order to accelerate redress of past unfair discrimination within the education and training system. There is congruence, therefore, between the aims of the research project and SAQA who are looking to the project to assist with more effective implementation of lifelong learning opportunities within higher education. Thus, the research is looking inwards to influence institutional policies and practices 'all the way down' (Edwards \& Thompson, 2013), and outwards towards influencing the NQF policy environments, all the way up. Built into the partnership with SAQA, were regular national seminars to engage people in the emerging research insights and the discourse of lifelong learning.

\section{UNDERSTANDINGS OF ACTION RESEARCH}

Action research is known by many names and each name implies different purposes, positionalities, epistemologies, ideological commitments and different research traditions (Herr and Anderson 2005). The line that we took is influenced by the participatory research approach (PRA) as defined in adult education literature (for example, Kassam 1982; Walters 1989, Hall 2001). This approach demands that the research integrates 'investigation, education and action'. PRA is a form of action research, which demands involvement rather than detachment. Coming out of the radical Freirian adult education tradition, it has a particular commitment to the educational value of the research process for all participants. It is this specific commitment, which is tied to the 'investigation and action' components which distinguishes it from some other forms of action research. Collins (2011) makes a very interesting link between PRA and Cultural Historical Activity Theory (CHAT) - through this he highlights, amongst others, the Marxist influences and the overt political nature of both, including how each tradition can serve to deepen the other.

PRA is different in some respects to much educational action research. As Elliott, cited by Ellis (2011:189) states, "the fundamental aim of action research is to improve practice rather than produce knowledge". Such an understanding of action research as practice implies a focus on action as behaviour without acknowledging the cultural and historical influence on behaviour. From a CHAT perspective knowledge (mind) is embedded in everyday interactions and active engagement with the world; that is, learning and development involves "practical and theoretical, material and mental, political and intellectual, social and individual ..." which rejects the separation between mind and action. Moreover, a CHAT line of reasoning emphasises the social/collective over 
individual/subjective analysis which enable us to analyse and interpret complex institutional conditions and factors which either enhance or impede creative responses. In our understanding PRA and CHAT reflect and support one another.

This congruence of PRA and CHAT has meant that we have been able to draw on the three conceptual tools within the CHAT tradition, which are at the core of this collection: common knowledge, relational expertise, and relational agency (See Chapter 1 and Edwards, 2010, 2012). These tools have allowed us, as a research team, to interrogate and analyse the responsive pedagogies within and across the three pilot sites. In doing so we have also been able to consider the extent to which they hold up to the pressures exerted in the highly charged and paradoxical environment we have just described.

\section{BUILDING COMMON KNOWLEDGE, RELATIONAL EXPERTISE AND RELATIONAL AGENCY IN PRACTICE}

Given that flexible learning and teaching means so many different things and is challenging the dominant approaches to teaching and learning in much of higher education, one premise of the proposal to Senate mentioned earlier was that a common understanding of what it means institutionally needed to be developed and embraced (DLL 2014). At a theoretical level, we found Edwards' (2011) notion of building 'common knowledge' useful as it speaks to the fact that bringing about change in institutions demands that it is not only the surface behaviours that require transformation, but there should also be a recognition of the historically accumulated motives that have given shape to the practices in which these behaviours occur and that these too need to be considered in relation to institutional adjustment. Accessing and discussing these often tacitly held historical motives requires deep and sustained dialogue. It therefore requires us as the core research team to develop and demonstrate relational expertise. As researchers working within the PRA tradition, we need to learn to take the standpoint of the other and understand how and why they are using the resources of flexible learning and teaching in the way that they are and to be explicit about what matters for us.

As Edwards (2011, p. 34) argues, in the process of exercising relational expertise_a 'discursive meeting of minds that gives rise to common knowledge' occurs. In this meeting of minds the motives that shape the practices of the other are surfaced and recognised in order to produce common knowledge, which then consists of these motives, or what matters, for each participant. This knowledge is held in common, is respected by the collaborators and brought into play to work on problems, in this case the development of flexible learning and teaching. In summary, in the study we are discussing here, common knowledge is elicited by the research team who also make what matters for them explicit, it then operates as a resource which mediates collaboration on the development of flexible learning and teaching strategies.

While common knowledge is a resource that is built by the research team using relational expertise, relational agency, is the capacity that is exercised when the action researchers in the three pilot sites work with the research team act together_such as to produce and implement flexible learning and teaching.

However, relational work of the kind we have outlined does not replace core professional knowledge and expertise. This has been one of the strengths arising for the integration of PRA with these three CHAT resources. As we have already indicated, the shifts we were hoping the study 
would engender required the ownership of the action researchers in the pilot sites. It was therefore crucial that we did not present ourselves as pedagogic experts who were intent on forcing the implementation of new strategies. Instead, we were able to create meetings of mind in which the specific pedagogic and curriculum requirements of each programme could be addressed in ways which respected what mattered for the programme.

While these conceptual tools have usefully augmented PRA they have also helped us to plan how we move forward from successful action research-based pilots to achieve the institutional shifts that support the new ways of working that are emerging. As we have already indicated, flexible learning and teaching provision is a complex problem involving the four inter-dependent sub-systems of the academy (Green et al., 2013), it will require committed collaboration across all systems and sectors within the institution in order to come to a common understanding of (FLTP) which includes the 'diversity' of students, including working students. Here we come to what Edwards (2012) has described as 'upstream learning', taking knowledge up through hierarchically ordered practices. There she has argued that the mobilisation of knowledge upwards, so that the institutional conditions necessary to support its production can be agreed, also involves the creation and deployment of common knowledge. This time the boundaries are horizontal, dividing different hierarchical layers in an organisation, rather than the vertical boundaries that, for example, separate departments and faculties in a university. Again there is a need for us, as PRA researchers, to be explicit about what matters to us about student access, while at the same time eliciting and working with what matters at the level of university administration. It is here that we have envisaged the contradictions to be most evident and most challenging to us as researchers.

One way of engaging with the motives of university administration and the financial constraints that have impeded their funding of the initiative is to invoke what Edwards and Thompson refer to as 'resourceful leadership' (Edwards \& Thompson, 2013). They argue that at a time of austerity, when material resources are stripped away and workforces are drastically reduced, as is the case in many universities, the remaining workforce becomes a vital resource and an overt focus for professional development and ensuring engagement with the long term purposes of the organisation. When these reductions are occurring at a time when fundamental change is required, then leadership must be able to recognise, enhance and give purpose to the capability of colleagues at every level of the systems they lead.

There is a strong link to development of 'common knowledge' on the part of the leader in their argument. The creative leadership that is required must listen, tap into and harvest the knowledge within innovations that are occurring at every level and assist with their movement upstream. We have argued that for flexible learning and teaching to become institutionalised in ways which will include a diversity of working and non-working students, changes need to impact every level of the institution, and the most senior levels therefore need to also have ownership. We concur with Johnston (1997) that both top-down and bottom-up change strategies are necessary; every person is a change agent and the best organisations learn from the external environment as well as from their own internal staff. Resourceful leadership, of the kind outlined here, is required to facilitate this occurrence.

We turn now to describing an illustrative example of how we have mobilised these concepts in practice. 


\section{TOWARDS AN INSTITUTIONAL POLICY ON FLEXIBLE LEARNNG AND TEACHING}

In order to ensure that the pilot sites would not remain separate silos of innovative pedagogy, we undertook a survey of work that could be labelled flexible learning and teaching across all faculties so that we could in some way engage non-participating units with the initiative. Through an international literature review, we honed in on a working definition of flexible learning and teaching. We then tested it in interviews with teaching and learning specialists and academics across all faculties, ensuring some discussion of what it might mean for them in their faculties and the university as a whole. The 31 semi-structured interviews were conducted by the team within a period of 10 days; the emerging results were fed back to a reference group of leading practitioners who formed a sub-committee of the Senate Teaching and Learning Committee (STLC) and acted as the project advisory group. There was also a workshop, to which all those who had been interviewed were invited, to give and get feedback on the survey and to clarify what a working definition of flexible learning and teaching could be.

In order to ensure that ideas were also fed upstream as well as horizontally, the research team made submissions of working documents to two Senate sub-committees. These documents were in various states of readiness and therefore took different forms.

The nature of the different documents at different stages included:

\begin{tabular}{|l|l|}
\hline (i) a preliminary research proposal which was invitational and tentative & 18 April 2013 \\
to solicit feedback on the idea for the research from the reference \\
group i.e. "Proposal for mapping flexible teaching and learning \\
provision at UWC"
\end{tabular}




\begin{tabular}{|c|c|}
\hline and teaching provision at UWC" & \\
\hline $\begin{array}{l}\text { (iv) a } 70 \text { page research report which was submitted to the Senate } \\
\text { Lifelong Learning Committee (SLLC) and this was referred to the } \\
\text { reference group i.e. "Draft Report. Mapping of flexible learning and } \\
\text { teaching at University of the Western Cape [UWC]". }\end{array}$ & 25 May 2014 \\
\hline $\begin{array}{l}\text { (v) a } 15 \text { page abbreviated report presented to the reference group; } \\
\text { where they asked for it to be reduced to } 12 \text { pages with some specific } \\
\text { requests, for there to be greater acknowledgement of work already } \\
\text { achieved i.e. "Flexible learning and teaching at UWC: } \\
\text { understandings, practices and implications [Draft report 2]" }\end{array}$ & 9 June 2014 \\
\hline $\begin{array}{l}\text { (vi) a } 12 \text { page abbreviated report which was submitted to the reference } \\
\text { group and was forwarded to the SLLC and STLC first meetings of } \\
2015 \text { i.e. "Flexible learning and teaching at UWC: } \\
\text { understandings, practices and implications. [Abbreviated } \\
\text { research report]" }\end{array}$ & 28 November 2014 \\
\hline $\begin{array}{l}\text { (vii) a project website and then a blog also was used to ensure that the } \\
\text { various mutations of the report and supporting documents were } \\
\text { publically } \\
\text { (http://uwcflexiblelearningandteaching.blogspot.com) }\end{array}$ & $\begin{array}{l}\text { February } \\
\text { onwards }\end{array}$ \\
\hline
\end{tabular}

In understanding the different mutations of the report, we have found Ellis' (2013, p202) heuristic device in the form of a quadrant, which highlights the relevance of each type of document, as useful. He, drawing on Burawoy's work, identifies two types of knowledge which are 'instrumental knowledge' and 'reflexive knowledge'. Instrumental types of knowledge are those that allow certain kinds of work to be accomplished, for example improved professional practice or policy related ends; while reflexive types of knowledge require dialogue about values and purposes underlying the development towards broader social goals (Ellis, p201). The two main audiences are 'academic', which are primarily academic scholarly communities concerned with critical knowledge, and 'extraacademic' which include politicians, bureaucrats, or the public. Both audiences require documents which speak to both instrumental and reflexive knowledge. We found that the university academics, in different contexts, could be seen to move from being 'academic' (i.e. part of a critical community of scholars) to 'extra-academic' (concerned to improve functioning) - at one point, reflexive knowledge was required as the document was judged by knowledge associated with critical evaluation of research within a wider intellectual context; and at another, instrumental knowledge where the documents needed to speak to policy and teaching practice. Depending on who was in the room at the time, the motives shifted and the political sensitivities were heightened or more muted. Therefore the mediation of the documents was critical. 
In reflecting back on the journey of the documents, we can observe that steps 2 and 4 in the Table reflect the need for critical academic engagement, while steps 3, 5 and 6 address the broader university public and the bureaucratic requirements of committees. In attempting to build common knowledge, steps 2 and 4 are concerned to engage in critical, scholarly conversations with colleagues, while the reports in steps 3,5 , and 6 are popularising the ideas amongst a broader university public.

The core research team, as boundary spanners, has had to be alert to 'what matters' to each of the individuals and to the collective in order to hear and understand whether it was possible to construct common knowledge. An example of this was one meeting of the advisory group, where a host of issues were being raised in relation to the 15 page abbreviated report (document 5 in Table) - at a point one of the researchers then asked of the group, 'what is the one thing that matters to all of us?' This was a significant moment of display of relational expertise which helped the atmosphere change from one of contestation to greater collaboration and collegiality; and helpful suggestions were made as to how the document could be altered in order to make its way successfully through the bureaucratic structures. The antagonisms of 'them ' and 'us', shifted to a sense of 'us'. There seemed to be a momentary emergence of collective ownership and relational agency. At a point of considerable pressure, relational expertise aimed at building common knowledge proved robust enough to tackle the contradictions that arise when a new way of working is introduced into an established

system.

The PRA has included investigation through collaborative research, education through sharing of findings and invitations to co-construct 'common knowledge' of flexible learning and teaching, through moving documents into the committees in order to influence changes in teaching and learning policy, and through supporting changes in teaching and learning within the pilot sites. The next five year Institutional Operating Plan (IOP) is currently being developed and the documents from the study are feeding into this process. In these ways we are attempting to move the knowledge generated in the pilots both horizontally and upstream.

\section{REFLECTIONS}

The study took place in an historical context which is marked by the authoritarian scars of a patriarchal, Apartheid state, within a historically black university which prides itself on its contribution to the struggle for liberation. The university is now caught in the cross winds of competitive globalisation and influenced by competition, regulation and commodification, raising questions about the process of building common knowledge in a system of flux. What are the capabilities required of researchers and leadership to bring about organisational innovation? How does the building of deep democratic practices, which common knowledge implies, sit alongside Castells' view that "Conflicts never end: they simply pause through temporary agreements and unstable contracts that are transformed into institutions of domination by those social actors who achieve an advantageous position in the power struggle. "..?

Earlier we outlined the politically charged environment of the study, which has been compounded by impending changes in senior leadership within the university. The short term timeframes of senior management have meant that they have been unable to operate as resourceful leaders and harvest the innovations and creative energies to be found in departments and faculties across the 
campus. This lack has meant that the building of common knowledge horizontally between departments and faculties has taken precedence in the study - in this we can claim some success. Moving the knowledge emanating from the action research upstream has been partial and it is still impossible to anticipate or predict success.

The main contradiction that the flexible provision action research is addressing is the 'binary' of day/night provision with full and part-time students in an institution which has a long history of support for poor and working students. The members of the research team, and the unit within which we work, has been a champion over 14 years of the black, working, and older students. The researchers therefore carry a certain moral authority in relation to the social justice mission of the university. This has paradoxically meant that we have been implicated in the social and political conflicts, also referred to as 'antagonisms' by Ellis. We have recognised the opportunity created by the contradiction in order to stimulate what Ellis $(2013$, p.211) refers to as 'difficult but transformative change'.

We have found that a cultural historical approach has offered tools from a radical interventionist tradition with developmental purposes. As Ellis (2013, p210) states, CHAT does not support 'knowledge transfer' but recognises interventions as contested spaces. This has been our experience as we have built common knowledge through relational expertise, which resonates with that of 'boundary spanners' managing ambiguous positions at the boundary (Ackermann et al 2011, p140). The competence has required careful listening to what really matters to people; a willingness to hear, to reformulate and to resubmit ideas, mediated through micro negotiations amongst individuals, and units; and inserting these ideas into the range of senate committees via both instrumental and reflexive documents, as appropriate. It also calls for what Landa (2008, quoted in Ackermann et al, p140) refers to as 'personal fortitude' and 'boundary skills'. It requires a long term perspective and commitment.

As Ellis reminds us, cultural historical theory supports development of pedagogy and design of learning environments at practical and organisational levels and cultural historical theory demands creative disturbance of existing practices - reconfiguration of practice implies transformation of sense-making through building common knowledge. It is inevitably a political process. In the context of the university, within a heightened political climate where some people may have seen the action research as a proxy for the larger struggle over the future direction of the university; so much more so.

This raises the question for us of the political nature of the building of common knowledge, which is a deeply democratic process. It demands sustained dialogue in order to identify collectively new understandings and new practices. In organisational environments where authoritarian leadership may prevail, building common knowledge may not be possible. Certainly moving knowledge like that generated in the action research pilots upstream will be that much more difficult. But even in democratic organisational cultures, if we accept Castells' view of organisations as "contradictory social structures enacted in conflicts and negotiations among diverse and often opposing social actors" is the building of common knowledge a 'moment' when conflicts "simply pause through temporary agreements and unstable contracts", where particular social actors achieve an advantageous position in the power struggle? 
In summary, we have drawn on 'common knowledge' to explain how new understandings of flexible pedagogy can be negotiated into practices within the university through use of 'relational expertise' within a participatory research approach. We have identified the political nature of organisational interventions which require conceptual tools which acknowledge the inevitable political contestations, and have therefore found 'common knowledge', 'relational expertise' and 'relational agency' very useful. In addition, for organisational interventions to succeed we suggest that 'resourceful leadership' is essential to move common knowledge upstream. (Edwards \& Thompson, 2013)

\section{References}

Ackermann, S. and Bakker, A. Boundary crossing and boundary objectives, in Review of Educational Research, June 2011, Vol 81, No 2.

Barnett R (2014) Conditions of flexibility: Securing a more responsive higher education system. The Higher Education Academy, January Available at: http://www.heacademy.ac.uk/resources/detail/flexible-learning/flexiblepedagogies/conditions of flexibility /main [Accessed 05.07.2014]

Breier, M. and Mabizela, M., (2008), Higher education. In A Kraak and K Press Ed. Human Resources Development. (Cape Town, HSRC Press), pp. 278-99.

Buchler, M., Castle, J., Osman, R. and Walters, S. (2007) Equity, access and success: adult learners in public higher education. In Council on Higher Education, Review of Higher Education in South Africa, Pretoria: Council on Higher Education, p. 124-56.

Burawoy, M. Redefining the public university: Global and national contexts, in Holmwood, J. (ed) (2011) A manifesto for the public university, London, Bloomsbury

Cape Argus, June, 2014, Cape Town

Castells, M. (2009) Communication Power, Oxford, Oxford University Press,

Collins C. (2011) Reflections on CHAT and Freire's participatory action research from the West of Scotland: Praxis, politics, and the 'struggle for meaningful life', in Mind, Culture and Activity, London, Routledge (Downloaded 4 November 2014)

Division for Lifelong Learning (2010) Clearing the ground: towards understanding and implementing flexible learning / teaching provision at UWC: update report on research. Bellville, UWC.

Division for Lifelong Learning (2014) Flexible learning and teaching at UWC: understandings, practices and implications: An abbreviated report, Bellville, UWC.

Edwards, A. (2010). Being an Expert Professional Practitioner: the relational turn in expertise. Dordrecht: Springer.

Edwards, A. (2011). Building Common Knowledge at Boundaries between Professional Practices. International Journal of Educational Research, 50: 33-39. 
Edwards, A. (2012). The role of common knowledge in achieving collaboration across practices. Learning, Culture and Social Interaction. 1(1) 22-32.

Edwards, A. Thompson, M. (2013) Resourceful Leadership: revealing the creativity of organisational leaders in A. Sannino and V. Ellis (Eds) Learning and Collective Creativity: Activity-Theoretical and Sociocultural Studies. London: Routledge. pp. 49-64.

Ellis, V. Teacher education in the public university: The challenge of democratising knowledge production, in Wells, G. and Edwards, A. Eds, (2013) Pedagogy in higher education: A cultural historical approach, Cambridge, Cambridge University Press

Green N, Woldoko B, Foskey R \& Brooks M (2013) Social media-enabled learning and the curriculum in Australian higher education: A literature review. DeHub Monograph Series, DEHub Innovation in Distance Education, University of New England, NSW, Australia

Hall, B. 2001 'I wish this were a poem of practices of participatory research' in Peter Reason and Hilary Bradbury (ed) Handbook of Action Research. Participative enquiry and practice, London, SAGE

Herr, K. and Anderson, G.L., (2005), The action research dissertation: a guide for students and faculty. California, USA: SAGE Publications.

Johnston S (1997) Introducing and supporting change towards more flexible teaching approaches. Conference paper presented at the Cambridge International Conference on Open and Distance Learning, 'The Convergence of Distance and Conventional Education: Patterns of Flexibility for the Individual Learner', Open University, Cambridge. Contained in a Collection of Conference Papers ISBN 0749288493

Kassam, Y. (1982) Participatory Research: An Emerging Alternative Methodology in Social Science Research, Dar Es Salaam, Black Star Agency

Republic of South Africa (RSA) 2013. White paper for Post-School Education and Training. Building an expanded, effective and integrated post-school system. 20 November, Department of Higher Education and Training, Pretoria.

Walters S. (1989) Education for democratic participation, Bellville, University of Western Cape

Walters S. (2012) 'South Africa: higher education in lifelong learning in a middle-income country: but by the grace of champions?' in Slowey, M., and Schuetze, H.G. eds. Global perspectives on higher education and lifelong learners, London and New York, Routledge. 